\title{
Quotations and Presumptions: Dialogical Effects of Misquotations
}

\author{
Douglas WaLton
}

Centre for Research in Reasoning, Argumentation and Rhetoric

Department of Philosophy

University of Windsor

Windsor, $O N$

Canada N9B 3P4

dwalton@uwindsor.ca

\section{FABRizio Macagno}

Institute of Philosophy of Language (IFL)

Universidade Nova de Lisboa

Edificio $I \& D$ - 4 andar

Avenida de Berna 26

1069-061 Lisbon

Portugal

fabrizio.macagno@fcsh.unl.pt

Abstract: Manipulation of quotation is shown to be a common argumentation tactic in this paper, but is also shown to be associated with fallacies like wrenching from context, hasty generalization, equivocation, and the straw man fallacy. Several examples are presented from everyday speech, legislative debates and trials. Using dialogue models we explain the critical defects of argumentation illustrated in the examples. Analyzing quotation by using the notion of commitment in dialogue, it is shown how an arguer's previous assertions can be verified to deal with problems arising from misquotation, and how a critic can correct the problem.
Résumé: Nous montrons dans cet article que la manipulation des citations est une tactique argumentative courante et qu'elle s'associe avec divers sophismes, tels que les citations arrachées de leur contexte, les généralisations hâtives, l'équivocation et l'homme de paille. Nous présentons divers exemples tirés des paroles de tous les jours, des débats législatifs et des procès. L'application de modèles dialogiques à nos exemples nous aident à expliquer les défauts importants de l'argumentation qui emploie cette manipulation. L'usage de la notion d'engagement dans un dialogue nous aide à analyser un tel emploi des citations et nous révèle comment nous pouvons vérifier si les assertions antérieures d'un argumentateur ont affaire aux problèmes qui surviennent des citations inexactes, et comment un critique peut corriger le problème.

Keywords: ambiguity, dialogue systems, fallacies, misquotation, straw man argument, profiles of dialogue

Manipulation of quotation is a common tactic in argumentation and it can be carried out quite deceptively in ways that are hard for a

(C) Douglas Walton and Fabrizio Macagno. Informal Logic, Vol. 31, No. 1 (2011), pp. 27-55. 
critic to pin down or for an opponent to deal with effectively. From an argumentative point of view, quotations are not only reported propositions, but acts in a discourse aimed at pursuing a specific communicative goal. Quotations are not merely repetitions of past assertions, but reminders of past commitments (Walton and Krabbe, 1995). On this perspective, misquotations are a particular type of speech act modifying the communicative setting. However, commitments are not argumentatively relevant if not directed to a dialogical goal, such as leading the interlocutor to change his position. For this reason, quotations and misquotations are strictly connected with other dialogical tactics, and in particular with straw man (Walton, 1996a; Johnson and Blair, 1983) and explicit or implicit personal attacks. Quotations are frequently used to remind the interlocutor of a past commitment conflicting with his present position or behaviour, so that he will either change his actual viewpoint or face the possibility of holding inconsistent commitments (Hamblin, 1970; Walton, 1995). This subtle threat implied in many cases of quotations is a powerful dialogical strategy, which the interlocutor has to tackle to avoid possible dialogical situations detrimental to his ethos. If we examine some cases of misquotation, we can notice how misquotes and personal attacks are closely related, and those attacks compel the other party to defend himself and provide evidence to rebut this accusation. Attacks based on misquotations change the dialogical situation and the dialectical game (Krabbe, 1999). As we will show, the connection between ad hominem strategies and quotations brings out some interesting features of the act of quoting, and shows how they can influence the burden of proof in dialogues.

In this paper, we present a corpus of dialectical uses of quotations and misquotations, so that the most common strategies based on them can be identified. The typologies of cases will be then examined using a pragmatic approach to quoting in which quotations will be studied from a linguistic and dialogical point of view. This theoretical approach is grounded on both argumentative studies and legal inquiries. The account will be shown to provide an explanation for the dialectical effects of the strategies based on misquotations.

\section{Strategies in quotations}

In order to see how quotation can be a prior step in setting up various fallacious moves in argumentation, the best place to begin is to study how quotations can be used as parts of different kinds of argumentation strategies. Use of a quotation can leave room for plausible deniability, because quoted statements are not necessarily commitments that can be attributed to the speaker who brought the 
quotation forward. A statement can be quoted for various purposes. It may even be quoted in order to attack it. Thus quotation does not automatically imply commitment. In this regard, we classify uses of quotations in two main categories: the ones used to support the argument of the quoted speaker and the ones used to attack it.

Many uses of quotation fall into neither of these categories. A speaker can quote in order to strengthen his own position, but only indirectly, without actually declaring her commitment to specific statements quoted. For example, decorative quotations and cultural quotations can be used to embellish the text and the words of the speaker. Plato and Cicero ${ }^{1}$, for instance, used quotation in their works to embellish and give dignity to what was said. Quotations may be used to affirm or identify with one's culture or traditions. They are often used in parliamentary debates to introduce and frame a discussion topic. Consider the following speech from the House of Lords (Young People and Democracy, col. 1460).

The general measures that I enunciated a moment ago are no substitute for dealing with the biggest outstanding issue that disconnects younger people from active democracy: the right to vote. In this Chamber in 1947, Winston Churchill famously said:

"No one pretends that democracy is perfect or allwise. Indeed, it has been said that democracy is the worst form of Government except all those other forms that have been tried from time to time"[Official Report, 11 November 1947; Vol. 444, c. 206-07.]

\footnotetext{
${ }^{1}$ For instance Cicero, in Ad Familiares 7.6., embellishes, strengthens and gives authority to his opinion about Trebatius' absence from Rome: «Tu modo ineptias istas et desideria urbis et urbanitatis depone et, quo consilio profectus es, id adsiduitate et virtute consequere. Hoc tibi tam ignoscemus nos amici quam ignoverunt Medeae "quae Corinthum arcem altam habebant matronae opulentae, optimates", quibus illa "manibus gypsatissimis" persuasit ne sibi vitio illae verterent quod abesset a patria. Nam "multi suam rem bene gessere et publicam patria procul; multi, qui domi aetatem agerent, propterea sunt improbati"» D.R. Shackleton Bailey, 1980, p. 52). The quotations from Ennius' Medea, referring to the possibility of helping his own country when abroad, and for this reason being forgiven by his own citizens, are in the same time ornament for the text and appeal to authority for Cicero's argument. See also P. Boller (1967, p. 3).

There is an example from Plato's Laws: here the quotation is used to support the thesis about the loyalty and courage in war: «[...] we say that there are still better men whose virtue is displayed in the greatest of all battles. And we too have a poet whom we summon as a witness, Theognis, citizen of Megara in Sicily :

'Cyrnus', he says, 'he who is faithful in a civil broil is worth his weight in gold and silver'» (Jowett, 1892, p. 412.)
} 
But what happens when there is a fundamental generational breakdown in democratic participation? That is the challenge we need to address today.

In this example, the discussion focuses on the reasons for the general breakdown in democratic participation. Churchill's quote is pivotal, because it points out that the democratic system is deficient in several aspects and is not perfect, but it remains the best form of government compared to all other ones. The debate is going to investigate why young people seem not to believe in democracy anymore, and why, in their opinion, it seems that democratic imperfections have overcome the positive aspects.

The two mentioned uses of quotation are not argumentation tactics designed to support a specific conclusion advanced at that point in the debate, nor do they imply commitments relevant to the argumentation being advanced at that point in the debate. Instead of having a functional role as supporting any precise claim made, they are only ornaments that set up a framework or ambience. In academic, literary, political, or other conversations, the discussion itself may become a pretext to show one's culture through the use of impressive quotations.

Quotations can sometimes be used, however, to support an appeal to authority argument designed to support one's argument. It is a common feature of argumentation in parliamentary debates that an authoritative source is quoted to support a speaker's position. For example, consider the following speech in which Sir Adam Roberts, professor of international relations at Oxford University, recently said that there was, in principle, a possible case for the lawfulness of resorting to war, but that the US and UK governments had overstated the Iraqi threat (Iraq, col. 1405). On the question of whether the Attorney-General's advice should be published, however, Roberts said:

Of course I'd like to see the full advice. What we have seen of the Attorney-General's advice does not deal with the key question of why the situation was deemed so urgent that inspectors had to be withdrawn and forces sent in.

On the question of legality, Malcolm Shaw, QC, Professor of Law at Leicester University, said:

On the basis of intelligence we had at the time and publicly available knowledge, there was a credible and reasonable argument in favour of the legality of war. 
The quotation is usually chosen from an authoritative or highly esteemed personality, or from the previous decisions of the government. The strength of these arguments lies in the association of knowledge or esteem and plausibility or truth. Quotations deployed in this way can shift esteem (gained by means of personal merit or scientific knowledge) from the quoted person to the argument. This concept may be better described as a shift of presumption: the quotation is presumed to have some kind of authority (moral or epistemic or both) and this presumption is transferred by the quoted words.

The argument from expert opinion must be based on critical features the source needs to have (Walton, 1997). The quoted source must be a real expert, competent in the particular field the statement quoted was used to support, its words must be correctly quoted, and they must be consistent with what other experts say. In addition, the topic in question should lie within a field where there is such a thing as authority. It is highly contestable whether there are authorities in fields such as morality. In this case, the notion of an 'expert' does not apply. The strategy of anonymous quotation avoids all these questions. The author is concealed and simply defined as "official source", "scientists", "knowledgeable", or with other epithets and attributes that can seem to strengthen the argument. A proper shifting of commitment based on expert opinion requires that the authority be named, and not merely made implicit without any name or institution being specifically quoted.

Another strategy to support one's own position is the use of quotations from the opposition. One side may show that the other is inconsistent. Or one may try to bolster one's own side by arguing that even an opponent has to acknowledge this particular thing, much as he/she has principles or intentions that would make $\mathrm{him} /$ her tend to disagree with it. The speaker's position may be, in fact, supported by the words of their attackers, or partisan of the attacker's standpoint. One of the best examples can be found in a discussion between the liberal Arthur Schlesinger and some conservatives about the welfare state. Schlesinger attacked a socialist reply by quoting Winston Churchill and a Republican senator. Their statements showed a position that clearly supported the welfare program ${ }^{2}$ : for this reason, Schlesinger concluded, the accusation of being socialist is thrown back onto Churchill and on the Republican senator.

\footnotetext{
${ }^{2}$ The first said: "the scheme of society for which we stand is the establishment and maintenance of a basic standard of life and labor below which a man or woman, however old or weak, shall not be allowed to fall. The food they receive, the prices they have to pay for basic necessities, the homes they live in, their employment must be the first care of the state, and must have the priority over all other peacetime needs" in Boller (1967, p. 85).
} 


\section{Quotations used to attack the other party}

To understand the examples treated below, it is necessary to begin by clarifying the relationship between ethos and position in a dialogue. Following Sperber and Wilson (1986, p. 58) we define the concept of informative intention as the intention to modify the cognitive environment of the audience. This concept is related to Peirce's notion of communication as habit change, as a means to modify the interaction conditions of the interlocutors, based on the theory that communication involves a change in the people involved. For this reason, statements must be supposed to be true, and the communicated information must be supposed to correspond to reality. The hearer cannot be changed if he thinks that the speaker lies, because her words will not have the intended communicative effect. The fundamental presupposition of communicative effect is trust in the speaker's words. For this reason, Grice (1975) expressed the maxim of sincerity as a pragmatic condition for goal-directed, collaborative communication: mutual understanding is based on the maxim that the speaker is presumed to be speaking truthfully.

From this point of departure, we can come to understand the relationship between words quoted and ethos that underlies the forms of argumentation used in ad hominem attacks. In Walton (1998, p. 112), the basic mechanism of the generic ad hominem argument utilizing personal attack is described as fitting the following argumentation scheme.

MAJOR PREMISE: If $x$ is ethically a bad person, then (generally) $x$ 's argument should not be accepted.

MINOR PREMISE: $\alpha$ is a bad person.

CONCLUSION: $\quad \alpha$ 's argument should not be accepted.

Aristotle in the Nicomachean Ethics called this kind of argument ethotic argument (Walton 1998, p. 200). The good or bad character of the respondent respectively enhances his credibility or detracts from it. This scheme is in principle a reasonable form of argumentation, based on a basic presupposition of successful communication. If the speaker is not trustworthy, and it is shown that he is likely to lie, it is reasonable to deny his words as an argument that should call for assent. The presupposition of assent is the hearer's trust in the speaker's ethos.

The argumentation scheme for the circumstantial ad hominem derives from the direct form cited above, by making a claimed inconsistency the basis of the argument. 
MAJOR PREMISE: If $x$ asserts proposition $A$, but then reveals that she is not personally committed to $A$ (or is even committed to the opposite of $A$ ), then $x$ is ethically a bad person and not a credible arguer, and her argument should not be judged to be plausible.

MINOR PREMISE: $\alpha$ asserted proposition $A$, but then $\alpha$ revealed that she was not personally committed to $A$ (or that she was committed to the opposite of $A$ ).

CONCLUSION: $\alpha$ is ethically a bad person and not a credible arguer, and her argument should not be judged to be plausible.

This argument is built on the citation of an alleged pragmatic contradiction $^{3}$, often based on a quotation, to mount a personal attack. It involves three parts. First, there is allegation of contradiction, a dialectical notion concerning commitment. Second, there is the use of the alleged contradiction to derive a conclusion about the arguer's ethos, a moral quality. Third, there is the inference, sometimes a hasty generalization, from a particular occurrence of an alleged contradiction to a more general overall judgement on the person's character.

In such ad hominem arguments, quotations may be used as the basis to attack the opponent's integrity. By recalling words stating position that appear to be contradictory with the present ones, the other party's ethos can be seriously damaged. This example from Hansard (Foreign and Commonwealth Affairs, 2004, col. 776) shows the use of previous commitments to attack the other party. In this case the ad hominem attack is not explicit, but masked under the innuendo of a sarcastic comment.

Mr. Webb: The hon. Gentleman says that its retrospective nature was one reason why he would not sign early-day motion 200. Two days ago, he was quoted in The Independent on Sunday: "We will be tabling an amendment to enable the pension protection levy to provide retrospective compensation". Was he misquoted?

\footnotetext{
${ }^{3}$ If person $A$ says "don't do $X$ " and then goes on and does $X, A$ is involved in a pragmatic contradiction. This is the kind of contradiction alleged in ad hominen arguments of the circumstantial type. It is not the same thing as $A$ asserting a proposition that is logically contradictory in the sense that it is reducible to the form ' $P$ and not- $P$ '
} 
Innuendo and irony are often used when the contradiction is not deep or serious enough to back accusations of inconsistency. Such attacks are a subtle way to damage another's credibility even if there is no sufficient basis. This example is from the crossexamination of Dr Rudolf Vrba (one of the authors of the famous War Refugee Board Report in 1944) in 1985 at the trial of Ernst Zündel in Toronto (Vrba's testimony, vol. VIII, p. 1630).

A. From outside I had been describing here a gas chamber that was visible from Krematorium I in front of my eyes, a distance of a few yards, which was coming out from the upper part of it, came out from the ground, and you were quarrelling with me if it was four feet or six feet high.

Q. Well, wait, now. Yesterday you told us it was six and a half to seven feet. Is it shrinking now?

Contradictions may arise between a document used in a process and other official sources. In this case the attack is directed towards the reliability of the document and was extended to the reliability of the author. The contradiction was used in this case to advance an attack his book as a fiction, and consequently support the thesis of the unreliability of his testimony (Vrba's testimony, vol. VIII, p. 1493).

Q. Let's go back and find out, then, about that, because I think you are wrong. Let's go back to the previous paragraph in your book that we discussed where you say twelve thousand bodies in twenty-four hours.

$[\ldots]$

Q. Why did you say in 1944, at the time of your escape, on page 16, at the bottom of the first paragraph: "Thus the total capacity of the four cremating and gassing plants at Birkenau amounts to about six thousand daily"?

A. That's right.

Q. Then why did you say in your book: "For the modern concrete gas chambers and the vast crematoria that could absorb as many as 12,000 bodies in twenty-four hours and, in fact, did so"?

A. What I had to add, that it did so with the help of additional equipment which has been build up in May and June 1944, after my escape. You might blame me that I haven't this made quite clear in this introductory chapter, but as I told you, this book is an artistic sort of conveying of the facts- - and is sufficiently giving the picture of what actually happened, without going into the fine toothpoint 
number game of which I have seen is a neo-Nazi literature - ridiculous examples.

Q. Well, is your book classified as fiction, or is it classified as history?

A. My book is classified as recollections of Rudolf Vrba, free recollection of Rudolf Vrba as an educational book for young people who should realize what Nazi depravity is able to do. It is not supposed to be a textbook of how to build crematoria.

MR CHRISTIE: I was trying to look at the realm of credibility and the basis of statements made by this witness in other circumstances. Often, this does involve a fact. In this case I don't think it is represented as hearsay, but now the War Refugee Board Report is the subject of the cross-examination, and it's not put forward as hearsay. In fact, if you look at the front of it, it says, "Nothing passed on from hearsay". My friend knows that because he gave me a copy. It says, "Nothing passed on from hearsay".

MR GRIFFITHS: That was not written by Dr. Vrba what my friend is describing. It is in a foreword.

MR CHRISTIE: Well, I took it that it was to be the truth.

The use of contradictions proved through quotation can be used to attack the other party even more deeply. Hasty generalization and straw man are the fallacies that arise in this example. The witness' quotations are confronted with the plans and reliable data. This confrontation is used to attack Mr. Vrba as a liar. From the imprecision of his testimony it is concluded that he is a liar (Vrba's testimony, vol. VIII, p. 1442).

Q. Mm-hmmm. You hated the Nazis, though, I assume from your answer; is that right?

A. I would say so. [...]

Q. Do you hate them enough to lie about them?

A. I have sworn on oath that here I will say the truth, and you will make an innuendo that I have lied in anything, then you would have to support it with some evidence, otherwise I would think badly about it.

Q. Well, I suggest to you that in your previous evidence you gave us to believe and told us as a fact that when the S.S. man climbed up on the long bunker, he had to reach up six and a half to seven feet. I put it to you that that is exactly what you said, sir, isn't it?
A. Is it? 
Q. I put it to you, and you are the witness, and you have the memory and you testified, I put it to you that's what you said.

A. I said, basically, that he had to reach up upon that bunker, and that bunker was, as far as I remember, certainly up to here if one would stand nearby, perhaps higher. So in other words he had to reach up and he had to climb. I didn't go there with a tape to measure if it was five or seven. You must understand that if I use such approximations, I am using them in order to make it more understandable to the jury and to the court of what approximately was involved, but they are not identical with engineering measurements.

Q. Well, you gave us to believe and you told us, as a matter of fact, and I put it to you that you said six and a half to seven feet.

A. Yes. [...]

Q. Now, I put it to you that the roof of the Leichenkeller to which you referred on the map ....[...]

Q. .... was actually parallel to and very close to the ground.

A. That is what you are putting to me?

Q. Yes. That's right.

A. How do you know that?

Q. Because I have seen the plans, if you want an answer.

Have you seen the plans?

In the following example (Foreign and Commonwealth Affairs, 2004, col. 833), contradictions derived from old promises confronted with the reality of facts. In this case, a person might be quoted to show that he promised to do $X$, and then evidence might be given that he did not in fact do $X$, contrary to what he promised. The accusation of inconsistency arises from the confrontation of the previous commitments about the protection of pension rights and funds with the loss of these funds. The claims about the efficiency of the proposals, and the confidence in the means and decision chosen to fulfil them, are undermined by the failure in keeping the promises. The opponents' credibility is highly damaged by showing that their statements were inconsistent with their actions. In this case, contradiction is used as an exhortation to fulfil what was said in the past, under the veiled accusation of incapability.

On 13 March 1995, Lord Mackay of Ardbrecknish said that the minimum funding requirement "will mean that members can be confident that the value of their accrued rights is secure, especially in the event of the scheme or 
the employer company winding up." That would apply to Chesterfield Cylinders, Dema Glass, Coalite, ASW or any of the other examples of which we have heard. Lord Mackay continued: "It is only right that the members' investment, and their accrued pension rights, should be properly protected. Our proposals are designed to provide that protection."-[Official Report, House of Lords, 13 March 1995; Vol. 562, c. 684.]

We have statements from Ministers in both Houses at the time of the 1995 Act saying "This will protect and guarantee your funds." We have documents from the Dexion group and from OPRA that seem to imply to people that by saving with such schemes they will be guaranteed safety, and that the financial sacrifice they are making to invest in their future will not be wasted.

In conclusion, I repeat that the Bill needs to do two things. First, it must provide justice for the estimated 60,000 people who have lost out in the past few years. Those people believed that they had a guaranteed and protected pension, for which many of them had saved for 30 or 40 years.

Argument from sign is another kind of argumentation scheme used in attacks following from contradictions. For instance, in the following case (Foreign and Commonwealth Affairs, 2004, col. 741), the contradictions in the statements cited are taken as a sign of the fact that the person does not act properly in the role she claims to play. Contradiction in this kind of argument is seen as a proof of lack of knowledge.

Mr. Boris Johnson (Henley) (Con): On the subject of bugging in the United Nations, what is any judge supposed to make of any future breach of the Official Secrets Act, given that the right hon. Member for Birmingham, Ladywood (Clare Short) is patently in breach of that Act and of her Privy Council oath and that the Government are too spineless and guilt-ridden to do anything about it?

$[\ldots]$

Mr. George Foulkes (Carrick, Cumnock and Doon Valley) (Lab/Co-op): Has the Foreign Secretary noticed that the claims made by my right hon. Friend the Member for Birmingham, Ladywood (Clare Short) have changed from day to day? First, she said that British intelligence was bugging Kofi Annan; then she said that the transcript came from someone else; and then she said the transcript 
38 Douglas Walton and Fabrizio Macagno

dealt with Africa, not Iraq. She has probably not breached the Official Secrets Act, but she has been very irresponsible.

These cases show that circumstantial ad hominem arguments can often be basically reasonable if evidence is offered that shows a circumstantial inconsistency in an author's quoted words, or between such words and her present deeds. They indicate how common such arguments are in legal cross-examinations, where they are used to raise doubts about the value of a speaker's testimony by raising doubts about her character for honesty. If an inconsistency of this sort suggests to a jury that the speaker is a hypocrite, the communicative effect can be powerful.

\section{Misquotation Strategies}

Wrenching from context is another common fallacy used to attack an opponent by distorting his words and committing him to positions he never actually held. The original words may be slightly changed, or torn out of context, licensing inferences that were not suggested in the original text. The pragmatic attitude of the speaker towards his own words may be distorted, misrepresenting the speech act or his original intentions. The words may be misattributed, wrongly paraphrased, or misinterpreted in order to adapt them to the desired line of argument. On the other hand, the accusation of wrenching from context is a frequent strategy used to try to retract one's own commitments, if they are shown to be problematic. In order to understand such strategies of attack by misquotation, it is necessary to examine retraction as a type of dialogue move (van Eemeren and Grootendorst, 1984). A previous or old commitment can be retracted by deleting it from an arguer's commitment set (Hamblin, 1971; Walton and Krabbe, 1995). Using this device, we can grasp the argumentation structure underlying strategies of misquotation.

The most common example of misquotation, and the easiest to deal with, is misattribution. Words never said by the accused are quoted as having been pronounced by him, and then the misquotation is used to attack him. This is often a weak and transparent strategy, since the respondent can easily dispute the truth of the attribution. For this reason, the misquotation is often embedded in a more complex move involving other fallacies. In the following case, from the Nuremberg trial, the misquotation is presupposed in a loaded question (The trial of German major War Criminals, p. 285). 
Q. Very well. I should like to ask you the following: When, in your speeches, you call Polish and Russian peoples "inferior people," when you insult them, don't you consider that these words express the racial theory?

A. Mr. Prosecutor, I should like to state that I never called the Russian people or the Polish people an inferior people.

Wrenching a proposition from context is often used to exaggerate a position or draw inferences from the quoted words that do not really represent the arguer's position. When the opponent's standpoint is thus distorted and demolished in order to refute him, for example by making his position appear more extreme, the tactic is called straw man. The following case is an example from the Nuremberg trial. The declaration of Fritzsche, an official responsible for propaganda, was torn from the contents and intentions of the whole speech, and then presented as a proof of his involvement in the persecution of Jews (The trial of German major War Criminals, p. 257).

Q. The prosecution quoted a passage from a speech which you made over the radio on 18th December, 1941. This speech will be found in full in my Document Book 1, Pages 26 to 32. In this instance, you said that the fate of Jewry in Europe had turned out to be as unpleasant as the Fuehrer predicted it would be in the event of a European war ... and that this unpleasant fate might also spread to the New World. The prosecution holds the view that this was a proclamation of further actions in the persecution of Jews. What can you tell us about this?

A. In this quotation, I discussed the unpleasant fate of Jewry in Europe. According to the things that we know today, this must look as though I meant the murder of the Jews. But in this connection I should like to state that at that time I did not know about these murders; therefore I could not have meant it. I did not even mean the evacuation of Jews, for even this fact was something which was not carried out in Berlin at least until a year or two later. What I meant was simply the elimination of Jews from politics and economic life. The expression "unpleasant" hints at this: otherwise it would be quite inexplicable because of its high meaning and as for the question: Why did I speak about the Jews in America in this connection? The sentence quoted by the prosecution is inextricably connected with a communication preceding it stating that a Jewish National Council had told President Roosevelt their wish to enter the war. Not even this 
40 Douglas Walton and Fabrizio Macagno

connection of thought, which is perhaps understandable now, was used by me without good reason. The largest part of this speech in question, perhaps nine-tenths of it, in fact, deals with the commission set up in the United States to investigate the causes of the Pearl Harbour disaster.

$[\ldots]$

DR. FRITZ: Mr. President, I believe that the defendant can stop at this point. He only wanted to show that the quotation of the last paragraph cited by the prosecution in order to incriminate him was torn from its contents.

Wrenching from context has often been labelled under the name "suppression of evidence" (Hurley, 1991, p. 263). Relevant parts of quotation are torn apart in such a way that the words quoted can assume a much more extreme meaning or a completely different one. This technique is often associated with the fallacy of ignoring qualifications and straw man.

Another tactic to build a straw man from the opponent quotation is quoting by changing specific words used to others that may have a similar meaning but convey incriminating inferences. In the following citation from the trial of Galileo, some quotes are manipulated by changing a word. The information conveyed by the text may be the same, or equivalent, but Galileo's position is completely twisted. In transcribing a letter by Galileo, Lorini changed two words and used the altered quotations as part of the argument against him (De Santillana, 1962, p. 45):

Galileo had written: "There are in Scripture words which, taken in the strict literal meaning, look as if they differed from the truth". Lorini wrote instead: "Which are false in the literal meaning". Galileo had written: "Scripture does not refrain from overshadowing [adombrare] its most essential dogmas by attributing to God qualities very far from and contrary to His essence". Lorini changed "overshadowing" into "perverting" (pervertire).

As seen in those examples, misquotation is not an end in itself, but a means to pursue a particular dialogical effect. Personal attacks and straw man strategies are the most common dialogical moves grounded on misquotations. The crucial issue that needs to be clarified is this relation between quotations and attacks, and in particular the dialogical effects of attacks following quotations. To untangle this question is useful to examine from an argumentative point of view the reaction of the interlocutor to a quotation or misquotation. 


\section{Retraction Strategies}

The strength of quotation lies in the fact that it brings to light statements made in the past. The interlocutor is confronted with propositions he used to be committed to, and these old commitments can either conflict with his actual position or be shameful in a specific context. When attacked based on quotes or misquotes, the interlocutor has to defend himself, and the most natural tactic is to show how the quotation can bear different meanings. A clear example can be given by the following text, excerpt from the Oscar Wilde trial, in which the poetic code is read without considering the metaphoric meaning of the words. The retraction strategy is aimed at showing the possible ambiguity of the words (Testimony of Oscar Wilde, 2004):

W-I am ready. I am never ashamed of the style of my writings.

G-You are fortunate, or shall I say shameless? (Laughter.) I refer to passages in two letters in particular?

W-Kindly quote them.

G-In letter number one you use the expression "Your slim gilt soul," and you refer to Lord Alfred's "red rose-1eaf lips." The second letter contains the words, "You are the divine thing I want," and describes Lord Alfred's letter as being "delightful, red and yellow wine to me." Do you think that an ordinarily constituted being would address such expressions to a younger man?

W-I am not happily, I think, an ordinarily constituted being.

G-It is agreeable to be able to agree with you, Mr. Wilde? (Laughter.)

W-There is nothing, I assure you, in either letter of which I need be ashamed. The first letter is really a prose poem, and the second more of a literary answer to one Lord Alfred had sent me.

G-You can, perhaps, understand that such verses as these would not be acceptable to the reader with an ordinarily balanced mind?

W-I am not prepared to say. It appears to me to be a question of taste, temperament and individuality. I should say that one man's poetry is another man's poison! (Laughter.) [...]

G-What is the "Love that dare not speak its name"? W-"The Love that dare not speak its name" in this century is such a great affection of an elder for a younger man as there was between David and Jonathan, such as Plato made the very basis of his philosophy, and such as you 
find in the sonnets of Michelangelo and Shakespeare. It is that deep, spiritual affection that is as pure as it is perfect. It dictates and pervades great works of art like those of Shakespeare and Michelangelo, and those two letters of mine, such as they are. It is in this century misunderstood, so much misunderstood that it may be described as the "Love that dare not speak its name," and on account of it I am placed where I am now. It is beautiful, it is fine, it is the noblest form of affection. There is nothing unnatural about it. It is intellectual, and it repeatedly exists between an elder and a younger man, when the elder man has intellect, and the younger man has all the joy, hope and glamour of life before him. That it should be so the world does not understand. The world mocks at it and sometimes puts one in the pillory for it. (Loud applause, mingled with some hisses.)

Mr. Justice Charles-If there is the slightest manifestation of feeling I shall have the Court cleared. There must be complete silence preserved.

G-Then there is no reason why it should be called "Shame"?

W-Ah, that, you will see, is the mockery of the other love, love which is jealous of friendship and says to it, "You should not interfere."

These cases are sufficient to show how subtle shifts in attributed meaning based on quotations can be used to attack the defendant in trials. In those cases, it is not sufficient that the defendant simply denies the quote: he has to explain why he has been misquoted, and provide evidence supporting his position.

Another possible reply for the interlocutor is to accuse the proponent of unfairness, shifting in this fashion the burden of proof. In the following example, a quotation is used to discredit a party, but the tactic used is not an explicit conclusion drawn, but only an implicit one drawn by innuendo. The respondent exaggerates the implicit message, and uses that straw man to move against the opponent, shifting the burden to his side. The quoted party needs to solve the problem posed by the apparent contradiction. If not, the attack moves forward. From an ad hominem attack, the attacking party moves on to a straw man attack, posing an extreme interpretation that shifts the burden of proof to the other side (Transports, 2004):

9 Mar 2004 : Column 1428

Llew Smith: I support such sentiments and I suspect that it is one of the reasons why a second resolution was not put to the UN at the time. Many hon. Members today 
wonder how a year ago they were able to vote for a resolution for war that asserted that this House: "recognises that Iraq's weapons of mass destruction and long range missiles, and its continuing non-compliance with Security Council Resolutions, pose a threat to international peace and security". - [Official Report, 18 March 2003; Vol. 401, c. 760.]

That was false. As Dr. David Kay, an ex-CIA agent and the former head of the Iraq survey group, which was set up to find the Iraqi weapons of mass destruction, put it to the United States Senate in January this year, after he resigned: "We were almost all wrong".

We now need to know whether Ministers simply proved to be very bad judges of geo-politics, stubbornly refusing to listen to the millions who marched against the war a year ago, or-worse-deliberately distorted the evidence, cherry-picked the details that suited their case for invading Iraq, and pressed the Attorney-General to provide an opinion that endorsed a political decision already taken two years earlier to invade Iraq and overthrow Saddam.

Mr. McCabe: I respect my hon. Friend's view on the war, although I do not agree with it. Is he seriously suggesting that Ministers in this Labour Government deliberately set out to lie, distort and misrepresent the truth to con us all into a war? Is that really what he believes?

This strategy may be described as a meta-discursive move, a metalevel comment on the dialogue and the dialectical exchanges that cannot be performed without an explicit attack to the other party. In ordinary debates, it is an allowed move, but in trials, this tactic is not available for the respondent. Trials are not debates, because the roles of the interlocutors are not on the same level. One party attacks and the other defends, and these positions cannot shift during the dialogue. The only reply the respondent can choose to an attack following a quotation is the retraction of commitment.

This is not easy, because the quoted party must satisfy a burden of proof in order to delete that commitment from its commitment store. It must persuade the opponent proving that it has never been committed to such a proposition. The tactic is to attack the inference drawn from the quotation by showing that its words have been misquoted or misrepresented. It is not relevant for our purposes to distinguish between real misquotations and presumed ones, but only to show how the defence should work in such cases. It is the dialectical move quoted that inserts the dark side commitments in the light one, and for this reason the 
allegation of misquotation is not itself a direct attack on the opponent, but an indirect metalinguistic move.

Quotations and misquotations, as seen above, are particularly powerful instruments when they trigger personal attacks, as they shift the burden of proof without any need to provide arguments except for the quote itself. Why are quotations so powerful? Why do attacks grounded on quotes shift the burden of proof without providing further arguments? In order to explain this relation between quotes and personal attacks, the argumentative structure of quotations will be analyzed.

\section{Misquotations and dialogues}

In the previous sections, different aspects of misquotations have been illustrated. Misquotations have been shown as strategies related to dialectical moves like straw man and personal attacks. In this section, we will focus on the structure of quotations and their dialogical and dialectical effects, to show how and why misquotations can play a powerful role in argumentation.

\section{Quotations as speech acts}

As seen in the previous sections, misquotation is an extremely effective strategy to attack or discredit another party. However, in order to understand the structure of the strategy of misquoting one's interlocutor's words, it is useful to analyze the structure of quotations. Quotations have been described in speech act theories (see Yamanashi 2001) in terms of the quoted speech act, not as dialogical independent moves. For instance, consider the following sentence (Yamanashi 2001: 228):

"I'll buy her a diamond ring," her husband said.

This sentence reports a promise and therefore is an assertive, while the quoted statement has an illocutionary force of promising. This analysis works for narrative texts, but in dialogical situations the act of reporting a quotation becomes a distinct act. For instance, we can compare the statement above to the following:

You must buy me a diamond ring. You promised it. Last week you told me: "I'll buy you a diamond ring".

The act of reporting a quotation does not simply report a speech act: it commits the quoted party, the interlocutor in this case, to the promised action. This mechanism can be understood from the relation between speech acts and commitments. A speaker's speech 
acts often result in his being committed to a certain proposition. For instance, promises commit the speaker to accomplish the promised action, while statements bind him to defend the stated proposition (see Searle 1969: 29; Searle 1979; Walton and Krabbe 1995). Commitments, however, do not result only from the present dialogue, but also from past conversations. For instance, present conversations may refer to what has been previously said, asked, or promised. However, time can delete commitments: for instance, the following statement would be hardly acceptable:

You are a bad person. When you were 10 you said, "I want to kill that squirrel".

Sometimes past dialogues may become part of the common knowledge regarding a person. Viewpoints, acts, opinions, confessions or narrations, when known by a community, become part of the shared knowledge about a speaker and his personality (see Perelman, Olbrechts-Tyteca 1951). Those commitments represent a person's reputation (Perelman, Olbrechts-Tyteca 1951, p. 257), which can be modified or affected by new actions or by pointing out unknown past actions. Past commitments, therefore, are not active parts of the dialogue a party is engaging in at present; they are hidden, dark-side commitments. Some of them are shared by the interlocutor and by the community, while others unknown. The former do not play an active part in the dialogue, but may influence the discussion as patterns for predicting the interlocutor's reactions, opinions, and therefore dialogical moves. The second are not dialogically relevant, unless they are brought to light. Quotations and misquotations intervene on hidden commitments, and are used to bring about specific dialogical and dialectical effects. Therefore, quotations are not simply assertives: they intervene on a dialogical setting in a twofold fashion. We can consider the following:

A. You are a bad person. Yesterday you said: "I want to steal Bob's car".

B. No, I did not say that.

A's speech act of quoting B's words commits A to the claim that B performed the reported speech act. Unlikely assertions, A's quotation also binds B to the commitments elicited by the quoted speech act. Unless B rebuts the quotation by advancing reasons, he will be committed to the quoted proposition, in this case.

From a dialectical point of view of analyzing quotations from the point of view of the interlocutors' commitments to perform specific dialogue moves, quotations are powerful instruments for 
shifting the burden of proof. The quoted interlocutor has a burden of proof to prove that the quotation was wrong in order to avoid being committed to it. This shift of the onus probandi is peculiar of quotations. Usually assertions result in commitments for the speaker, and consequently the burden of supporting them if challenged. Quotations, on the contrary, result in the interlocutor being committed to the quoted propositions, and he has the burden to provide reasons to reject the misquotation.

Misquotations have the same dialogical effect, but they mischievously disguise commitments invented by the quoting party as interlocutor's past or unknown commitments. While quotations insert old commitments into the interlocutor's commitment store, misquotations place new propositions in it without any need to advance arguments. Quotations and misquotations are generally presumed to be true until contrary and sufficient evidence is produced.

\section{Dialogical effects}

Quotations can be considered instruments for making known and unknown dark-side commitments relevant to the dialogue. They insert commitments into the interlocutor's commitment store, and he has to either defend them or justify a possible retraction. In both cases, quotations may be used to support a standpoint, or influence the shared evaluation of the speaker, for instance by highlighting past positions commonly accepted as negative. These uses are also the two most important purposes of misquotation. If we consider the legal dialogue as a model of everyday dialogues, in which the rules have been clearly set forth, we notice that misquotations can modify the dialogical situation in two crucial fashions. By misquoting a principle of law, or a clause in a contract, it is possible to warrant conclusions that otherwise would have been unsupported by the wording of the quoted document. Moreover, by misquoting a person's words, it is possible to depict him differently from what he actually is, or he is considered to be.

The first use can be illustrated by the following case. In Dillard Trucking v. Athwal, A116309 (2008), Dillard, a trucking firm, and Athwal, who acted as subhauler for Dillard, filed a motion asking that they be awarded attorney fees for a previous litigation due to Athwal's actions. They both supported their claims based on a fee cause in their contract. Athwal quoted the clause as follows:

Subhauler is responsible for attorney's fees, which Prime Carrier may suffer or incur, from any act or omission of Subhauler because of the failure of Subhauler's insurance 
carrier to defend any legal action against Prime Carrier arising out of such action or incident. (Emphasis added.)

As Athwal was the subhauler, and no fees were caused by the failure to Athwal's insurance carrier to defend any legal action that might be filed, he had not to pay. However, the actual provision of the contract stated as follows:

Subhauler is responsible for attorney's fees, which Prime Carrier may suffer or incur, from any act or omission of Subhauler or because of the failure of Subhauler's insurance carrier to defend any legal action against Prime Carrier arising out of such action or incident.

The actual contract clause imposed the obligation to pay attorney fees in case of any act or omission; as the parties went to trial because of Athwal's actions, the latter had to pay the legal costs.

The second dialogical effect is explained in Masson v. New Yorker Magazine, 501 U.S. 496 (1991). In this judgment, the judge distinguished between two types of misquotation that can be considered defamatory. In the first type of misquotation an untrue factual assertion is attributed to the speaker. For instance, a journalist could fabricate a quotation of a public official admitting he had been convicted of a serious crime when in fact he had not. In the second type of misquotation, the truth or the falsity of the factual matters asserted are not relevant. The crucial aspect is that the speaker never asserted the quoted statement, and this false attribution may result in injury to reputation because the manner of expression or its meaning indicate a negative personal trait of the speaker. For instance, John Lennon was quoted once as saying of the Beatles, "We're more popular than Jesus Christ now." (Time, Aug. 12, 1966, p. 38). If this quotation had been a fabrication, even if it had been true it would have been considered as defamatory, as the mere attribution could have damaged the speaker's reputation (Masson v. New Yorker Magazine, 501 U.S. 496 (1991)).

\section{Evaluating misquotations}

In law, misquotations can be evaluated according to different factors. A misquotation is dialogically relevant if they are used to accomplish dialogical moves, as seen above. However, a quotation has to satisfy certain standards in order to be considered a misquotation. These conditions are clearly set out in Masson $v$. New Yorker Magazine, 501 U.S. 496 (1991). Masson, a psychoanalyst, was fired after advancing his own theories. Thereafter, Malcolm, an author and contributor to New Yorker Magazine, taped 
several interviews with Masson and wrote a lengthy article on his relationship with the archives. Malcolm enclosed in his article lengthy passages attributed to Masson in quotation marks, which were alleged by Masson as mistaken and defamatory. After the publication of the article, a book was published, which portrayed Masson in a most unflattering light. Masson brought an action for libel. The court discussed six passages according to two standards.

The first factor is the ambiguity of the act of quoting somebody (see Longacre 1983, p. 87). For instance, a quotation made by a speaker in a conversation is different from a quotation by a reporter or by a counsel in court. In the latter case, the quotations report the speaker's actual words, while in the first case the quotations may not "convey that the speaker actually said or wrote the quoted material" (Masson v. New Yorker Magazine, 501 U.S. 496 (1991)). "Punctuation marks, like words, have many uses. Writers often use quotation marks, yet no reasonable reader would assume that such punctuation automatically implies the truth of the quoted material" (Baker v. Los Angeles Examiner, $42 \mathrm{Cal}$. 3d at 263, 721 P.2d at 92). For instance, in historical fictions, or in some forms of documentaries, the quotations should not be interpreted as the actual statements of the speaker to whom they are attributed. On the contrary, in journalistic writing if no clues or explicit declarations are provided, the reader is led to believe that the quotations are being used as a rhetorical device or to paraphrase the speaker's actual statements. In Milkovich v. Lorain Journal Co., 497 U.S. 1 (1990), at 17, the distinction between an actual quote and a mere opinion is articulated in three standards:

(1) Is the language loose, figurative, or hyperbolic, which would negate the impression that the speaker was seriously maintaining the truth of the underlying facts?

(2) Does the general tenor of the article negate the impression that the speaker was seriously maintaining the truth of the underlying fact?

(3) Is the connotation sufficiently factual to be susceptible of being proved true or false?

The second element is the relation between the quoted words and the intended meaning. Not every alteration of the wording of a quote results in a change in meaning. In order for a deliberate alteration to be classified as a false quote, the meaning of the quoted statement must be materially changed (Masson v. New Yorker Magazine, 501 U.S. 496 (1991)). The crucial issue is to determine what "material change" means. Different statements may convey the same "descriptive" meaning, but triggering quite different inferences. The same person can be referred to as "the elderly maid" or "the old spinster", leading the interlocutor to 
different judgments on the referent (see Stevenson 1937). The following case can explain this distinction (Masson v. New Yorker Magazine, 895 F.2d (1989) at 1541). The analyst, Masson, was quoted as stating in discussing an affair with a graduate student:

Eissler and Anna Freud told me that they like me well enough "in my own room." They loved to hear from me what creeps and dolts analysts are. I was like an intellectual gigolo - you get your pleasure from him, but you don't take him out in public." (Emphasis added.)

The actual statement was the following:

[Eissler and Anna Freud] felt, in a sense, I [Masson] was a private asset but a public liability. They like me when I was alone in their living room, and I could talk and chat and tell them the truth about things and they would tell me. But that I was, in a sense, much too junior within the hierarchy of analysis, for these important training analysts to be caught dead with me.

The district court opined further that "the descriptive term 'intellectual gigolo,' as used in this context, simply means that Masson's views were privately entertaining, but publicly embarrassing to Freud and Eissler". The Supreme Court, however, reversed that judgment maintaining that (Masson v. New Yorker Magazine, 501 U.S. 496 (1991) at 521) "fairly read, intellectual gigolo suggests someone who forsakes intellectual integrity in exchange for pecuniary or other gain". Even though the two statements conveyed the same descriptive meaning, the inferences and the value judgment the quotation elicited were different, and this modification was held to be a material change, as it affected the evaluation of the speaker.

Misquotations should be therefore evaluated under different points of view. The act of quoting can hide the ambiguity between an actual quotation or a mere paraphrase; the words can be different but convey the same meaning; and the meaning can be the same, but the inferences can be different. A misquotation occurswhen the speaker communicates that the quotation is an actual quotation, and at the same time modifies the descriptive or evaluative meaning of the quotation.

\section{Misquotations and burden of proof}

In law, the problem of placing the burden of proof in cases of misquotation is controversial. Usually the burden of proof is placed 
on the plaintiff, namely the person who has been misquoted. He has to prove that the quoted statement was in fact different from his actual words. However, misquotations are frequently used to achieve a specific move, and one of the most common strategies is the use of misquotation to discredit the quoted person. The defense against such attacks is to accuse defamation, which places the burden of proof on the defendant. A defamatory statement is presumed to be false unless the defendant can prove its truth (Philadelphia Newspapers, Inc. v. Hepps, 475 U.S. 767 (1986)). The allocation of burden of proof is of material importance, especially when it is not possible to assess the truth or the falsity of the quotation. In everyday conversation, we hardly keep a record of our past statements, and not always can we rely on witnesses. In those cases, the allocation of the burden of proving determines the truth or the falsity of the quote (Philadelphia Newspapers, Inc. v. Hepps, 475 U.S. (1986) at 1564):

the allocation of the burden of proof will determine liability for some speech that is true and some that is false, but all of such speech is unknowably true or false. Because the burden of proof is the deciding factor only when the evidence is ambiguous, we cannot know how much of the speech affected by the allocation of the burden of proof is true and how much is false.

For this reason, in order to protect the freedom of speech, when the defendant in a defamation lawsuit works in the media industry and the speech is of public concern, the burden of proof is placed on the plaintiff. These controversial aspects of the allocation of the burden of proof show how crucial onus probandi is in cases of misquotation. The burden of proving the truth or the falsity of the quotation involves requisites that in everyday conversation can be hard to fulfill. Ambiguity, interpretation, and lack of knowledge due to the absence of records or testimonies, make the dialectical aspect of proving the falsity or the truth of a quotation both crucial burdensome.

\section{Contradictory quotes, profiles of dialog and misquotation moves}

As seen above, misquotations are instruments to manipulate the interlocutor's commitments. Contrary to statements, misquotations modify the other party's commitments without any need of arguments to support this move. However, in a context of dialogue, misquotations are useless unless they are used to support a further conclusion. The second crucial aspect of misquotations is the 
allocation of the burden of proof. In law, the presumptions upon which the allocation of the burden of proof rests is that a quotation is usually true until proven false, and a defamatory statement is presumed to be false unless the defendant can prove its truth, and unless the context is a public speech. These two features of misquotation can help explain the relation between misquotations and the related dialogue moves.

The first dialogical feature of misquotations is their use in ad hominem attacks based on contradictory commitments. Misquotations are never neutral: highlighting one of the interlocutor's dark side commitments results in confronting him with the risk of inconsistency. For instance consider the following case:

Bob is a communist. Yesterday you said that Bob was member of the communist party.

In this case, the respondent either accepts the conclusion, or resolves the inconsistency by showing that the conclusion does not follow from the previous commitment, or attacks the truth or correctness of the quotation. While in law the rules of the allocation of the burden of proof are relatively clear, in everyday conversation clear rules are just an ideal. Most of the time, there are several possible scenarios:

(1) A. Bob is a communist. Yesterday you said that Bob was member of the communist party.

B. I never said that.

(2) A. Bob is a communist. Yesterday you said that Bob was member of the communist party.

B. I never said that. I simply I have seen Bob along with some communists.

(3) A. You are a communist! You said that communism is the true political system.

B. I never said that! You are just making it up to discredit me!

(4) A. You are a communist! You said that communism is the true political system.

B. I never said that!

A. Ah really? Now you are changing your mind?

In the first case, the allocation of the burden of proof is uncertain. The dialogue is at a deadlock, and only if A or B defends his position regarding the truth or falsity of the quotation can it be 
considered successful from a persuasive point of view. The allocation of the burden of proof here is bound to the possibility of proving a position. Presumption in law is a type of rule related to the reasonableness of allocating the burden of providing evidence or arguments, and depends on the availability of proofs to the parties. The allocation of the burden of proof (Aydin Corp. v. First State Ins. Co., 18 Cal.4th 1183 (1998)) depends on

a number of factors: the knowledge of the parties concerning the particular fact, the availability of the evidence to the parties, the most desirable result in terms of public policy in the absence of proof of the particular fact, and the probability of the existence or nonexistence of the fact.

Ordinary conversation is not governed by clear rules; however, the principles underlying legal procedural rules regarding the burden of proof cast light on the aspects of reasonableness in a persuasion dialogue. The absence of a clear procedure can be bridged therefore by the same principles that lay at the basis of legal rules. In everyday conversation, where there is not a clear record of the past dialogical moves, in absence of witnesses the only means to support a quotation is one's own testimony. Therefore, either the misquotation is similar to the original, and the quote manipulates the commitments and exploits the potential ambiguities of the interlocutor's words, as in (2), or the parties resort to metalinguistic tactics for allocating burden of proof. In this latter event, the parties may appeal to direct attacks to lead the interlocutor to prove or disprove the misquotation in order to defend his position. In (3), the respondent allocates the burden of proving that the quotation is true on the proponent by accusing him; in (4) A's unsupported denial is used against him as a premise for a personal attack.

A dialogue on a specific issue normally rests on some presumptions. For instance, a witness is presumed to tell the truth, or a statement contrary to the common opinion is presumed to be not acceptable. The acceptance of a persuasive type of dialogue, aimed at reaching an agreement about a specific issue, involving the acceptance of a set of shared presumptions, which result in a clear allocation of the burden of proof. Personal attacks do not only shift a persuasion dialogue to other types of dialogue like quarrel, but, more deeply, exploit other types of presumption, as the shared knowledge that "the facts alleged in the complaint are true", or that the facts in a defamation are false. Attacks are therefore so powerful because they intervene on the burden of proof. Allegations of inconsistency or personal attacks grounded on misquotes do not need complex arguments, as they rest on the presumption that quotations are true; moreover, they block the 
interlocutor's possible moves, as he has to defend himself from the accusation and cannot simply deny the quote. In order for a misquotation to be successful, it must avoid both deadlocks and possible attacks of falsity or defamation. In order to take effect, the misquotation must be confused with the real quotation, must be difficult to prove to be different from the real one, or must be simply associated with other moves such as attacks of inconsistency.

\section{Conclusion}

This paper provided an analysis of the fallacy of misquotation and related sophisms from a dialogical point of view. Misquotations become powerful dialogical instruments when they are premises for personal attacks or they are used to divert the interlocutor's viewpoint. In particular, it was shown through the selected examples how the manipulation of quotation is extremely effective when associated with an explicit or implicit conclusion stemming from moves made in a dialogue that reveal the speaker's inconsistency. The deceptive strength of strategic manipulation as an argumentation tactic lies in the dialogical use of distorted commitments as a way to shift the burden of proof or to block respondent's possible replies. The analysis of misquotation in law provides a clear understanding of how the strategies stemming from misquotations affect the dialogical setting by exploiting presumptions shifting the burden of proof.

Acknowledgements: Douglas Walton thanks the Social Sciences and Humanities Research Council of Canada for the research grant, 'Argumentation in Artificial Intelligence and Law', that supported the work in this paper. Fabrizio Macagno thanks the Università Cattolica del Sacro Cuore for a research grant and the Fundação para a Ciência e a Tecnologia for the research grant PTDC/FILFIL/110117/2009 (Argumentação, Comuni-cação e Contexto).

\section{References}

Boller, P.F. (1967). Quotemanship. Dallas: Southern Methodist University Press.

De Santillana, G. (1962). The Crime of Galileo. New York: Time INC.

Dunne, P.E., Doutre, S., and Bench-Capon, T. (2005). Discovering Inconsistency through Examination Dialogues, Proceedings 
54 Douglas Walton and Fabrizio Macagno

IJCAI-05 (International Joint Conferences on Artificial Intelligence), Edinburgh, 1560-1561. Available at: http://ijcai.org/search.php

Hamblin,C.L.(1971) Mathematical Models of Dialogue, Theoria, 37, 130-155.

Hamblin, C.L. (1970). Fallacies. London: Methuen.

Johnson, R.H. and J.A. Blair. (1983). Logical Self-Defence, 2nd ed., Toronto, McGraw-Hill Ryerson, .

Jowett, B. (1892). The Dialogues of Plato, Vol.II. New York: Random House.

Krabbe, E.C.W. (1999). Profiles of Dialogue. In J. Gerbrandy, M. Marx, M. de Rijke \& Y. Venema (eds.), JFAK: Essays Dedicated to Johan van Benthem on the Occasion of his $50^{\text {th }}$ Birthday (pp. 25-36). Amsterdam: Amsterdam University Press.

Longacre, R.E. (1983). The grammar of discourse. Topics in Language and Linguistics. New York and London: Plenum Press

Perelman C., \& L. Olbrechts-Tyteca. (1951). Act and Person in Argument. Ethics 61 (4): 251-269

Searle, J. (1979). Expression and meaning: studies in the theory of speech acts. Cambridge: Cambridge University Press.

Shackleton Bailey, D.R. (1980). Cicero Select Letters. Cam-bridge: Cambridge University Press.

Sperber, D. \& Wilson, D. (1986). Relevance. Oxford: Blackwell.

Stevenson, C. L. (1937). The Emotive Meaning of Ethical Terms. Mind 46: $14-31$

Van Eemeren, F.H. \& Grootendorst, R. (1984). Speech Acts in Argumentative Discussions, Dordrecht: Foris.

Walton D. (2006). Examination Dialogue: An Argumentation Framework for Critically Questioning an Expert Opinion. Journal of Pragmatics, 38, 745-777.

Walton, D. \&. Krabbe, E.C.W. (1995). Commitment in Dialogue: Basic Concepts of Interpersonal Reasoning. Albany (NY): State University of New York Press.

Walton, D. (1984). Logical Dialogue-Games and Fallacies, Lanham, University Press of America.

Walton, D. (1995). A Pragmatic Theory of Fallacy. Tuscaloosa (AL): University of Alabama Press.

Walton, D. (1996). Fallacies Arising from Ambiguity. Dordrecht: Kluwer.

Walton, D. (1996a). The Straw Man Fallacy. In J. van Benthem, R. Grootendorst \& F. Veltman (eds), Logic and Argumentation (pp. 115-128). Amsterdam: Royal Netherlands Academy of Arts and Sciences.

Walton, D. (1997). Appeal to Expert Opinion, University Park (PA): Penn State Press. 
Walton, D. (1998). Ad Hominem Arguments. Tuscaloosa (AL): University of Alabama Press.

Yamanashi, M. (2001). Speech-act construction. In Vanderveken, D. \& S. Kubo (eds.), Essays in Speech Act Theory, pp. 225-238, Amsterdam: John Benjamins Publishing Company,

\section{Web pages}

Linder, D.O. Testimony of Oscar Wilde, retrieved 8 June, 2004, from

http://www.law.umkc.edu/faculty/projects/ftrials/wilde/Crimwilde. $\underline{\mathrm{html}}$

The United Kingdom Parliament (2 March 2004). Foreign and Commonwealth Affairs. Retrieved 4 June 2004 from

http://www.parliament.the-stationeryoffice.co.uk/pa/cm200304/cmhansrd/cm040302/debtext/40302$\underline{11 . h t m}$

The United Kingdom Parliament (9 March 2004). Transport. Retrieved 4 June 2004 from http://www.publications.parliament.uk/pa/cm200304/cmhansrd/vo0 40309/debindx/40309-x.htm

Vrba's testimony. Retrieved 6 June 2004 from http://www.vho.org/aaargh/engl/vrba3.html

The Trial of German Major War Criminals. Retrieved 8 June 2004 from

http://www.nizkor.org/hweb/imt/tgmwc/tgmwc-17/tgmwc-17-16504.shtml

The United Kingdom Parliament (9 March 2004). Young People and Democracy. Retrieved 4 June 2004 from

http://www.publications.parliament.uk/pa/cm200304/cmhansrd/vo0 40309/debtext/40309-28.htm

The United Kingdom Parliament (9 March 2004). Iraq. Retrieved 4 June 2004 from

http://www.publications.parliament.uk/pa/cm200304/cmhansrd/vo0 40309/debtext/40309-12.htm 